\title{
Interannual variability of isotopic composition in water vapor over western Africa and its relationship to ENSO
}

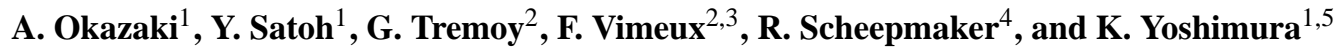 \\ ${ }^{1}$ Institute of Industrial Science, University of Tokyo, Tokyo, Japan \\ ${ }^{2}$ Laboratoire des Sciences du Climat et de l'Environnement, UMR8212, Institut Pierre Simon Laplace, \\ CEA-CNRS-UVSQ, Gif-sur-Yvette, France \\ ${ }^{3}$ Laboratoire HydroSciences Montpellier, UMR 5569, Institut de Recherche pour le Développement, \\ CNRS-IRD-UM1-UM2, Montpellier, France \\ ${ }^{4}$ SRON Netherlands Institute for Space Research, Utrecht, the Netherlands \\ ${ }^{5}$ Atmosphere and Ocean Research Institute, University of Tokyo, Kashiwa, Japan \\ Correspondence to: A. Okazaki (okazaki@rainbow.iis.u-tokyo.ac.jp)
}

Received: 27 May 2014 - Published in Atmos. Chem. Phys. Discuss.: 22 September 2014

Revised: 27 January 2015 - Accepted: 6 February 2015 - Published: 20 March 2015

\begin{abstract}
This study was performed to examine the relationship between isotopic composition in near-surface vapor $\left(\delta^{18} \mathrm{O}_{\mathrm{v}}\right)$ over western Africa during the monsoon season and El Niño-Southern Oscillation (ENSO) activity using the Isotope-incorporated Global Spectral Model. The model was evaluated using a satellite and in situ observations at daily to interannual timescales. The model provided an accurate simulation of the spatial pattern and seasonal and interannual variations of isotopic composition in column and surface vapor and precipitation over western Africa. Encouraged by this result, we conducted a simulation stretching 34 years (1979-2012) to investigate the relationship between atmospheric environment and isotopic signature on an interannual timescale. The simulation indicated that the depletion in the monsoon season does not appear every year at Niamey. The major difference between the composite fields with and without depletion was in the amount of precipitation in the upstream area of Niamey. As the interannual variation of the precipitation amount is influenced by the ENSO, we regressed the monsoon season averaged $\delta^{18} \mathrm{O}_{\mathrm{v}}$ from the model and annually averaged NINO3 index and found a statistically significant correlation $(R=0.56, P<0.01)$ at Niamey. This relationship suggests that there is a possibility of reconstructing past western African monsoon activity and ENSO using climate proxies.
\end{abstract}

\section{Introduction}

The El Niño-Southern Oscillation (ENSO) is the strongest mode of interannual variability in the tropics (Dai et al., 1997) and plays an important role in the variability of precipitation, temperature, and circulation patterns on this timescale. El Niño can cause catastrophic floods and droughts (Philander, 1983) and damage to ecosystems (Aronson et al., 2000). A recent study projected an increase in the frequency of extreme El Niño events due to global warming (Cai et al., 2014). Therefore, it is essential to understand the natural variability of ENSO. Stable water isotopes (D, ${ }^{18} \mathrm{O}$ ) have been used to infer past and present climate since the work of Dansgaard (1964). Several studies have linked ENSO with isotopic variation in precipitation or in seawater under the present climate (e.g., Schmidt et al., 2007; Yoshimura et al., 2008; Tindall et al., 2009). For example, tropical South America (Vuille and Werner, 2005), the western and central Pacific (Brown et al., 2006), and the Asian monsoon region (Ishizaki et al., 2012) are identified as having a connection with ENSO, basically through changes in local rainfall or integrated rainfall along the trajectory. However, other regions, such as western Africa, have not yet been investigated in detail.

Western Africa receives most precipitation in the monsoon season (July-September; JAS) and is known for its high variability on interannual or longer timescales. The severe 
drought that hit western Africa during the 1970s and 1980s prompted researchers to study the factors controlling western African rainfall variability on interannual to multidecadal timescales (e.g., Folland et al., 1986; Palmer, 1986; Janicot et al., 1996; Giannini et al., 2003; Shanahan et al., 2009; Mohino et al., 2011a, b). At present, the major role of sea surface temperatures (SST) in driving the variability, with land-atmosphere interactions as an amplifier (Giannini et al., 2003), is widely recognized. However, there is still debate regarding the relative importance of the various basins and mechanistic timescales involved (Nicholson, 2013). The Atlantic (Lamb, 1978; Joly and Voldoire, 2010; Mohino et al., 2011a), Pacific (Janicot et al., 2001; Mohino et al., 2011b), Indian Ocean (Palmer et al., 1986), and Mediterranean (Rowell, 2003; Polo et al., 2008) have been linked to the variability of west African rainfall. In these oceans, the ENSO is thought to modulate the high-frequency component (interannual) of the variability (Ward, 1998; Joly et al., 2007). However, the relationships are not stationary over time; the western African rainfall is correlated with ENSO only after the 1970s (Janicot et al., 2001; Losada et al., 2012), indicating the existence of multiple competing physical mechanisms. How the impact has changed remains an open question.

Several studies used isotopes to understand the water cycle over western Africa on the intraseasonal timescale. Risi et al. (2008b) and Tremoy et al. $(2012,2014)$ examined the isotopic compositions of precipitation $\left(\delta^{18} \mathrm{O}_{\mathrm{P}}\right)$ and vapor $\left(\delta^{18} \mathrm{O}_{\mathrm{v}}\right)$, respectively, and both found that $\delta^{18} \mathrm{O}$ records the spatially and temporally integrated convective activity during the monsoon season. Here, $\delta$ in per mill units is defined as $\left(R_{\text {sample }} / R_{\text {std }}-1\right) \times 1000$, where $R_{\text {std }}$ is VSMOW (Vienna Standard Mean Ocean Water). Risi et al. (2010) confirmed the relationship using the LMDZ-iso model and suggested that $\delta^{18} \mathrm{O}$ is controlled by convection through rain reevaporation and the progressive depletion of the vapor by convective mixing along air mass trajectories. The relationship between $\delta^{18} \mathrm{O}$ and convective activity suggests the possibility of reconstructing the convective activity using a climate proxy if the relationship holds on the interannual timescale. The long record of precipitation should help in determining how SSTs influence precipitation variability. Some studies have reconstructed precipitation over western Africa (Lézine and Casanova, 1989; Shanahan et al., 2009). Shanahan et al. (2009) directly tied isotopic composition to local precipitation. However, it is possible that the amount of rainfall along the trajectory rather than local information has a greater impact, as mentioned above. Therefore, it is still necessary to estimate the relative contributions of the main controls on the interannual variability of the isotopic composition in more comprehensive way.

In this paper, we explore the factors governing the interannual variability of monsoon season $\delta^{18} \mathrm{O}_{\mathrm{v}}$, which is the source of precipitation and controls $\delta^{18} \mathrm{O}_{\mathrm{p}}$ variability (Risi et al., 2008a), over western Africa and how the ENSO signal is imprinted. As the observations cover relatively short periods for looking into the interannual variability and available variables are limited, we use an isotope-enabled general circulation model (GCM) to complement the observations.

In the following section, the model simulations and the observations are described. In Sect. 3, we compare the simulated and observed variability of $\delta^{18} \mathrm{O}$ on a daily to interannual timescale. Section 4 investigates the factors controlling $\delta^{18} \mathrm{O}_{\mathrm{v}}$ on the interannual timescale by analyzing the simulation results and confirms the role of the identified factors by sensitivity experiments. Finally, we examine the relationship between $\delta^{18} \mathrm{O}$ and ENSO in Sect. 5 .

\section{Data and methods}

\subsection{Observations}

\subsubsection{Observation of HDO in vapor from space}

Frankenberg et al. (2009) measured column-averaged isotopologue ratio $(\delta \mathrm{D})$ values in water vapor using the SCanning Imaging Absorption spectroMeter for Atmospheric CHartographY (SCIAMACHY) onboard the European research satellite ENVISAT. We used the updated and extended version of this data set from Scheepmaker et al. (2014), covering the years 2003-2007. As measured $\delta D$ is weighted by the $\mathrm{H}_{2} \mathrm{O}$ concentration at all heights, it is largely determined by the isotopic abundance in the lowest tropospheric layers, where most water vapor resides. The footprint of each measurement is $120 \mathrm{~km}$ (across-track) $\times 30 \mathrm{~km}$ (alongtrack). We apply the following selection criteria concerning the retrievals (Scheepmaker et al., 2014):

- Retrieved $\mathrm{H}_{2} \mathrm{O}$ total column must be at least $70 \%$ of the a priori value.

- The $\mathrm{CH}_{4}$ column in the same retrieval window must be at least within $10 \%$ of the a priori value.

- Root-mean-square variation of the spectral residuals must be below $5 \%$.

- Convergence must be achieved in a maximum of four iteration steps.

Here, the first two criteria restrict large deviations from the a priori $\mathrm{H}_{2} \mathrm{O}$ and $\mathrm{CH}_{4}$ columns, which are normally the result of light scattering by clouds. Therefore, these two criteria function as a simple cloud filter. Due to the high detector noise of SCIAMACHY in the shortwave infrared channels, the single measurement noise $(1 \sigma)$ is typically $40-100 \%$, depending on total water column, surface albedo, and viewing geometry. For the region of our study, however, the mean single measurement noise is of the order of $20-50 \%$, due to the high albedo and optimal viewing geometry of western Africa. This random error can be further reduced by averaging multiple measurements. Therefore, we average the measurements according to the procedure of Yoshimura et 
Table 1. Locations and operational periods of the GNIP observatories used in this study.

\begin{tabular}{lrrr}
\hline Station name & Latitude & Longitude & $\begin{array}{r}\text { Operation } \\
\text { period }\end{array}$ \\
\hline Tunis & & & $16^{\circ} 50^{\prime} \mathrm{N}$ \\
Algiers & $36^{\circ} 47^{\prime} \mathrm{N}$ & $3^{\circ} 04^{\prime} \mathrm{E}$ & $1967-2006$ \\
Sfax & $34^{\circ} 43^{\prime} \mathrm{N}$ & $10^{\circ} 41^{\prime} \mathrm{E}$ & $1998-2006$ \\
Fes Sais & $33^{\circ} 58^{\prime} \mathrm{N}$ & $4^{\circ} 59^{\prime} \mathrm{W}$ & $1994-2008$ \\
Sidi Barrani & $31^{\circ} 38^{\prime} \mathrm{N}$ & $25^{\circ} 57^{\prime} \mathrm{E}$ & $1978-2003$ \\
Bamako & $13^{\circ} 42^{\prime} \mathrm{N}$ & $8^{\circ} 00^{\prime} \mathrm{W}$ & $1962-2007$ \\
Niamey & $13^{\circ} 29^{\prime} \mathrm{N}$ & $2^{\circ} 05^{\prime} \mathrm{E}$ & $1992-2009$ \\
N'Djamena & $12^{\circ} 08^{\prime} \mathrm{N}$ & $15^{\circ} 02^{\prime} \mathrm{E}$ & $1960-1995$ \\
Addis Ababa & $9^{\circ} 00^{\prime} \mathrm{N}$ & $38^{\circ} 44^{\prime} \mathrm{E}$ & $1961-2009$ \\
São Tomé & $0^{\circ} 23^{\prime} \mathrm{N}$ & $6^{\circ} 43^{\prime} \mathrm{E}$ & $1962-1976$ \\
Entebbe & $0^{\circ} 03^{\prime} \mathrm{N}$ & $32^{\circ} 27^{\prime} \mathrm{E}$ & $1960-2006$ \\
Kinshasa & $4^{\circ} 22^{\prime} \mathrm{S}$ & $15^{\circ} 15^{\prime} \mathrm{E}$ & $1961-1972$ \\
Diego Garcia & $7^{\circ} 19^{\prime} \mathrm{S}$ & $72^{\circ} 26^{\prime} \mathrm{E}$ & $1962-2003$ \\
Dar es Salaam & $6^{\circ} 53^{\prime} \mathrm{S}$ & $39^{\circ} 12^{\prime} \mathrm{E}$ & $1960-1976$ \\
Ascension Island & $7^{\circ} 55^{\prime} \mathrm{S}$ & $14^{\circ} 25^{\prime} \mathrm{W}$ & $1961-2009$ \\
Malanje & $9^{\circ} 33^{\prime} \mathrm{S}$ & $16^{\circ} 22^{\prime} \mathrm{E}$ & $1969-1983$ \\
Ndola & $13^{\circ} 00^{\prime} \mathrm{S}$ & $28^{\circ} 39^{\prime} \mathrm{E}$ & $1968-2009$ \\
Menongue & $14^{\circ} 40^{\prime} \mathrm{S}$ & $17^{\circ} 42^{\prime} \mathrm{E}$ & $1969-1983$ \\
St Helena & $15^{\circ} 58^{\prime} \mathrm{S}$ & $5^{\circ} 42^{\prime} \mathrm{E}$ & $1962-1975$ \\
Harare & $17^{\circ} 48^{\prime} \mathrm{S}$ & $31^{\circ} 01^{\prime} \mathrm{W}$ & $1960-2003$ \\
Antananarivo & $18^{\circ} 54^{\prime} \mathrm{S}$ & $47^{\circ} 32^{\prime} \mathrm{E}$ & $1961-1975$ \\
St-Denis & $20^{\circ} 54^{\prime} \mathrm{S}$ & $55^{\circ} 29^{\prime} \mathrm{E}$ & $2001-2009$ \\
Windhoek & $22^{\circ} 57^{\prime} \mathrm{S}$ & $17^{\circ} 09^{\prime} \mathrm{E}$ & $1961-2001$ \\
Pretoria & $25^{\circ} 43^{\prime} \mathrm{S}$ & $28^{\circ} 10^{\prime} \mathrm{E}$ & $1958-2001$ \\
Malan & $33^{\circ} 58^{\prime} \mathrm{S}$ & $18^{\circ} 36^{\prime} \mathrm{E}$ & $1961-2009$ \\
Cape Town & $33^{\circ} 57^{\prime} \mathrm{S}$ & $18^{\circ} 28^{\prime} \mathrm{E}$ & $1995-2008$ \\
Gough Island & $40^{\circ} 21^{\prime} \mathrm{S}$ & $9^{\circ} 53^{\prime} \mathrm{W}$ & $1960-2009$ \\
Marion Island & $46^{\circ} 53^{\prime} \mathrm{S}$ & $37^{\circ} 52^{\prime} \mathrm{E}$ & $1961-2009$ \\
\hline & & & \\
\hline
\end{tabular}

al. (2011); we averaged multiple measurements that were collected in a grid of $2.5^{\circ} \times 2.5^{\circ}$ in $6 \mathrm{~h}$. We set the threshold value for averaging to 10 , meaning that the average of the SCIAMACHY measurements in every grid cell is based on at least 10 measurements taken within $6 \mathrm{~h}$. From the Isotope-incorporated Global Spectral Model (IsoGSM) simulation results, the times of the nearest satellite measurements were extracted (hereafter the process is called "collocation"). Thus, there was no difference in representativeness between the model and the satellite data.

\subsubsection{In situ measurement of water isotopologues in vapor}

To assess the performance of the model on shorter timescales, daily $\delta^{18} \mathrm{O}_{\mathrm{v}}$ from Tremoy et al. (2012) was used in this study. The $\delta^{18} \mathrm{O}_{\mathrm{v}}$ was observed at about $8 \mathrm{~m}$ above the ground using a Picarro laser instrument (L1102-i model) with an accuracy of $\pm 0.25 \%$ at the Institut des Radio-Isotopes in Niamey, Niger (IRI; $13.31^{\circ} \mathrm{N}, 2.06^{\circ} \mathrm{E} ; 218 \mathrm{~m}$ a.s.l) from 2 July 2010 to 12 May 2011.

\subsubsection{In situ measurement of isotopes in precipitation (GNIP)}

Observations of the monthly isotope ratio in precipitation over western Africa were obtained from the Global Network for Isotopes in Precipitation (GNIP) observational database (IAEA/WMO, 2014). We chose 28 GNIP stations in Africa that have full annual data spanning more than 10 years. The observatory location and its operation period are summarized in Table 1.

\subsection{Isotope-enabled general circulation model simulation}

The IsoGSM is an atmospheric GCM, into which stable water isotopes are incorporated. The model uses T62 horizontal resolution (about $200 \mathrm{~km}$ ) and 28 vertical levels, and the temporal resolution of the output is $6 \mathrm{~h}$. The convection scheme is the relaxed Arakawa-Schubert scheme (Moorthi and Suarez, 1992). The main time integration scheme is a leapfrog scheme. The model is spectrally nudged toward wind and temperature fields from the National Centers for Environmental Prediction (NCEP)-Department of Energy (DOE) Reanalysis 2 (R2) (Kanamitsu et al., 2002) in addition to being forced with prescribed SST and sea ice from an NCEP analysis, which are the same as those used in NCEP-DOE R2 (Kanamitsu et al., 2002). After a spinup period of about 10 years with the constant 1979 forcing, the simulation was run from 1979 to 2012, as in Yoshimura et al. (2008). Isotope processes were incorporated following Joussaume et al. (1984): isotopic fractionation takes place whenever phase transition occurs. Most fractionation can be assumed to occur at thermodynamic equilibrium, except for three particular cases: surface evaporation form open water, condensation from vapor to ice in supersaturation conditions under $-20^{\circ} \mathrm{C}$, and evaporation and isotopic exchange from liquid raindrop into unsaturated air. IsoGSM assumes no fractionation when water evapotranspires over land. More details of the model configurations have been described previously (Yoshimura et al., 2008). The general reproducibility of the model for daily to interannual timescales is well evaluated by comparing it with the precipitation isotope ratio (Yoshimura et al., 2008) and the vapor isotopologue ratio from satellite measurements (Yoshimura et al., 2011), and it showed sufficiently accurate results for various process studies (e.g., Berkelhammer et al., 2012; Liu et al., 2013, 2014).

In addition to the standard experiment (Std) mentioned above, we carried out two sensitivity experiments. The first of these experiments examined the sensitivity of the results to the "equilibrium fraction $\varepsilon$ ", which is the degree to which falling rain droplets equilibrate with the surroundings. Risi et al. (2010) reported the importance of reevaporation for $\delta^{18} \mathrm{O}_{\mathrm{v}}$ over western Africa, and Yoshimura et al. (2011) found an improved simulation result with the changed parameter. Following Yoshimura et al. (2011), we set this value to $10 \%$, 
while in the standard simulation it was set to $45 \%$. The other sensitivity experiment was intended to estimate the contributions to interannual variability in $\delta^{18} \mathrm{O}_{\mathrm{v}}$ of the distillation effect during transportation from the source regions. In this experiment, we removed the influences of the distillation processes by turning off isotopic fractionation during condensation and reevaporation from raindrops and preventing isotopic exchange between falling raindrops and the surrounding vapor. Note that these effects were switched off only in a certain region in the simulation. For a similar purpose, Ishizaki et al. (2012) specified transport pathways and then removed these effects along the pathway. We chose a different means of removing the effects in a certain domain, as we wished to specify the area that plays an important role in controlling the isotopic variation at a given point. Hereafter, we refer to the former sensitivity experiment as the "E10" experiment and the latter as the "NoFrac" experiment. Std and NoFrac cover the 1979-2012 period, and E10 covers the 2010-2011 period. The simulation results used in this study are from Std unless otherwise noted.

We use both $\delta \mathrm{D}$ and $\delta^{18} \mathrm{O}$ in the evaluation of the model since SCIAMACHY observes $\delta \mathrm{D}$, whereas Tremoy et al. (2012) observes $\delta^{18} \mathrm{O}$. As $\delta \mathrm{D}$ and $\delta^{18} \mathrm{O}$ basically respond to meteorological factors in the same way, there are no differences in underlying mechanisms to produce changes. Therefore, there is no problem in using the combination of $\delta \mathrm{D}$ and $\delta^{18} \mathrm{O}$ to evaluate model performance. In Sects. 4 and 5 we consistently use $\delta^{18} \mathrm{O}$.

\subsection{Isoflux analysis}

Isoflux analysis specifies the contributions of advection, evapotranspiration, and precipitation to the changes in the isotopic composition of precipitable water in an atmospheric column. The concept of the analysis is based on budget analysis. Using such analysis, Lai et al. (2006) specified the factors controlling $\delta^{18} \mathrm{O}_{\mathrm{v}}$ in a canopy layer. Worden et al. (2007) discovered the importance of reevaporation from raindrops. Here, we develop the mass balance equation for ${ }^{18} \mathrm{O}$ in the atmospheric column. The mass balance for total precipitable water inside the atmospheric column can be written as

$$
\frac{\mathrm{d} W}{\mathrm{~d} t}=-\nabla \cdot Q+E-P
$$

where $W$ represents the total precipitable water, $\boldsymbol{Q}$ is the vertically integrated two-dimensional vapor flux vector, $E$ is evapotranspiration, and $P$ is precipitation. The term $\nabla \cdot \boldsymbol{Q}$ denotes the horizontal divergence of vapor flux. Here, we refer to this term as advection. A mass balance equation can also be written for ${ }^{18} \mathrm{O}$ in the same manner as Eq. (1).

$$
\frac{\mathrm{d} R_{\mathrm{W}} W}{\mathrm{~d} t}=-\nabla \cdot R_{\mathrm{W}} \boldsymbol{Q}+R_{\mathrm{E}} E-R_{\mathrm{P}} P,
$$

where $R_{\mathrm{W}}, R_{\mathrm{E}}$, and $R_{\mathrm{P}}$ represent the isotope ratio $\left({ }^{18} \mathrm{O} /{ }^{16} \mathrm{O}\right)$ of precipitable water, evapotranspiration, and precipitation, respectively. Multiplying Eq. (1) by $R_{\mathrm{W}}$ and subtracting that from Eq. (2), we obtain

$\frac{\mathrm{d} R_{\mathrm{W}}}{\mathrm{d} t} W=-\nabla R_{\mathrm{W}} \cdot \boldsymbol{Q}+\left(R_{\mathrm{E}}-R_{\mathrm{W}}\right) E-\left(R_{\mathrm{P}}-R_{\mathrm{W}}\right) P$.

Dividing by the $R_{\text {std }}$, we can rewrite Eq. (3) in $\delta$ notation as

$\frac{\mathrm{d} \delta_{\mathrm{W}}}{\mathrm{d} t} W=-\nabla \delta_{\mathrm{W}} \cdot \boldsymbol{Q}+\left(\delta_{\mathrm{E}}-\delta_{\mathrm{W}}\right) E-\left(\delta_{\mathrm{P}}-\delta_{\mathrm{W}}\right) P$.

Starting from the left, the terms represent the temporal derivative of the isotopic composition of precipitable water, the effect of advection, evapotranspiration, and precipitation to deplete or enrich the precipitable water. As the analysis specifies the contribution of each factor to the change in isotopic composition of precipitable water, the analysis period should start before the initiation of isotopic depletion and end at the most depleted point. We use the $6 \mathrm{~h}$ output of IsoGSM to calculate each term in Eq. (4); then each term is averaged over the targeting period and compared.

\section{Evaluation of IsoGSM}

\subsection{Evaluation of IsoGSM at the mean state and seasonal climatology}

The annual mean climatology of the SCIAMACHY data and the collocated IsoGSM fields together with precipitable water by JRA25 (Japanese 25-year ReAnalysis; Onogi et al., 2007) and the model are shown in Fig. 1. In the SCIAMACHY data, the meridional gradient over western Africa is notable; the lowest values of $\delta \mathrm{D}$ were found in the Sahara and the highest on the Guinea coast. This is due to the dry and therefore HDO-depleted air mass from the subsiding branch of the Hadley circulation in the dry season over the Sahara and strong evaporation and/or recycling of water in the tropics (Frankenberg et al., 2009). IsoGSM simulates this spatial pattern qualitatively well. Although the average is negatively biased (about 20\%o) (Yoshimura et al., 2011) and the latitudinal gradient is weaker in IsoGSM, bias and overestimated gradient are found in SCIAMACHY when compared with ground-based Fourier-transform spectrometers (Scheepmaker et al., 2014). Accordingly we cannot conclude whether such differences from the satellite are indeed problematic or not at this stage.

Figure 2 shows time-latitude diagrams of $\delta \mathrm{D}$ and precipitable water averaged on $5^{\circ} \mathrm{W}-5^{\circ} \mathrm{E}$ from 2003 to 2007. Over the region, vapor $\delta \mathrm{D}$ is high and wet in the monsoon season and low in the dry season. In the monsoon season, the wet and isotopically heavy vapor comes from the south, along with the monsoon flow. The northern end of the flow coincides with the location of the Intertropical Discontinuity (ITD), which limits the extension of the monsoon flow (Janicot et al., 2008). In the dry season, the subsiding branch of the Hadley cell brings a dry and depleted air mass to the north of the area (Frankenberg et al., 2009). At around $10^{\circ} \mathrm{N}$, 

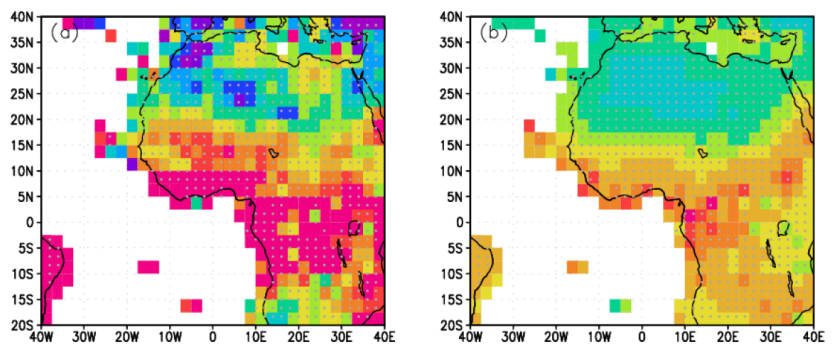

\begin{tabular}{llllllllll|l}
-190 & -180 & -170 & -160 & -150 & -140 & -130 & -120 & -110 & -100 & -90
\end{tabular}
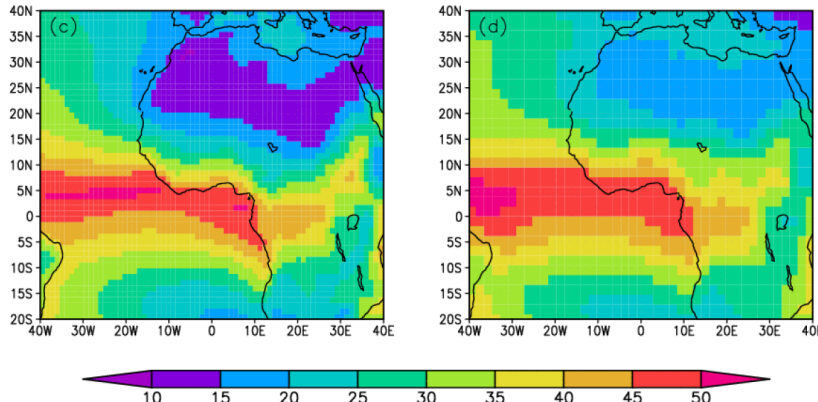

Figure 1. Annual mean $\delta \mathrm{D}(\%)$ in column vapor by (a) SCIAMACHY and (b) collocated IsoGSM. Regions in which the measurements did not pass the retrieval criteria were left blank. The shaded grid with dots represents the mean value of the average, which consists of at least 10 measurements within every $6 \mathrm{~h}$. Annual mean precipitable water $\left(\mathrm{kg} \mathrm{m}^{-2}\right)$ by (c) JRA25 and (d) IsoGSM is also shown.

$\delta \mathrm{D}$ has two minima: one in winter, reflecting the depleting effect of subsidence, and the other in summer, reflecting the depleting effect of convective activity (Risi et al., 2010). The model captures these two regimes and the depleting effect of convective activity around $10^{\circ} \mathrm{N}$ in the monsoon season. The Pearson product moment correlation coefficient (hereafter we use the term "correlation" unless otherwise noted) between the observed and simulated zonally averaged $\delta \mathrm{D}$ $\left(5^{\circ} \mathrm{W}-5^{\circ} \mathrm{E}\right.$ ) is 0.77 (significance level: $P<0.001$ ). Note that the range is widely different between them $(-300-0 \%$ o for SCIAMACHY; $-190-90 \%$ for IsoGSM). This may be because IsoGSM misses the enrichment in boreal summer over tropical Africa, as suggested in previous studies (Frankenberg et al., 2009; Yoshimura et al., 2011). The bias in the mean field (Risi et al., 2010; Werner et al., 2011; Lee et al., 2012) and the underestimated seasonality (Risi et al., 2010) are also common in other GCMs. Again, the bias in SCIAMACHY has also been indicated (Scheepmaker et al., 2014), and Risi et al. (2010) pointed out the possibility that SCIAMACHY may overestimate the variability by preferentially sampling high altitudes.

Then we compared the simulated $\delta^{18} \mathrm{O}_{\mathrm{v}}$ with in situ measurements from Tremoy et al. (2012) at the Niamey grid point over the 2010-2011 period. Figure 3 shows the time series of near-surface daily $\delta^{18} \mathrm{O}_{\mathrm{v}}$ from the observation and
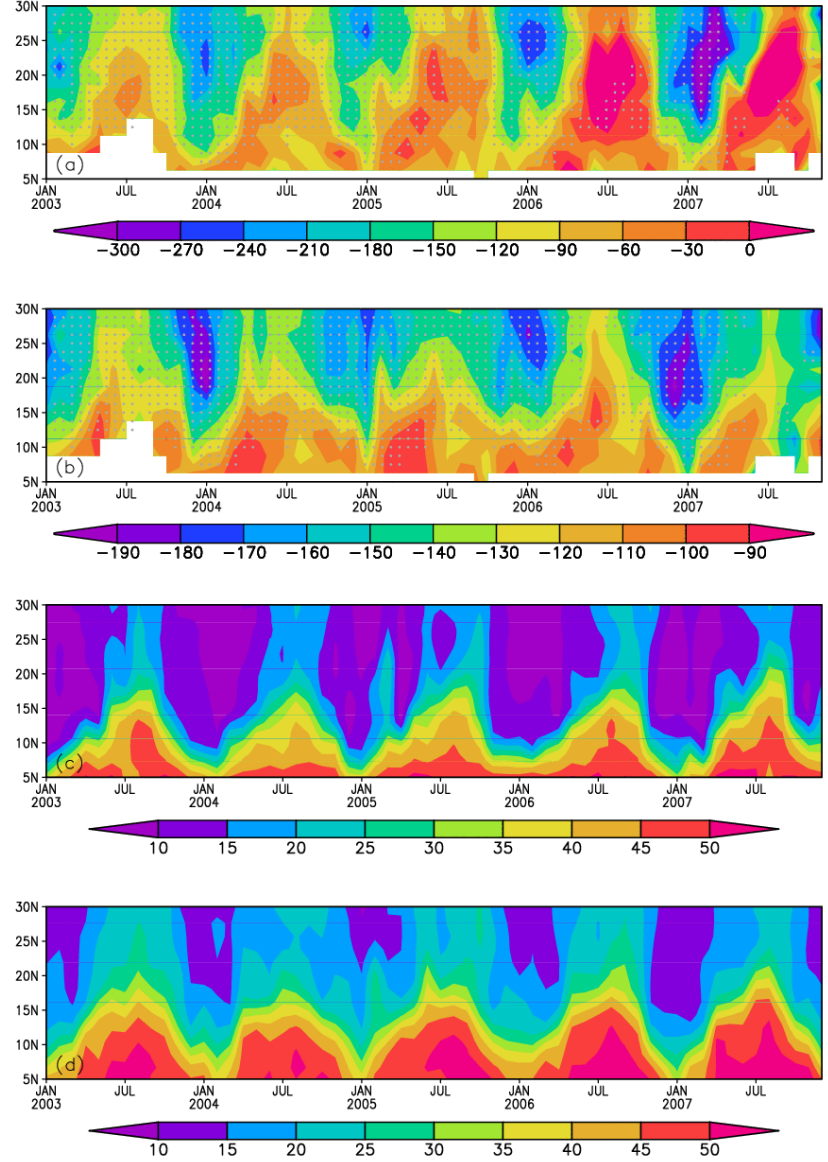

Figure 2. Time-latitude diagrams of $\delta \mathrm{D}(\%$ ) in column vapor averaged over $5^{\circ} \mathrm{W}-5^{\circ} \mathrm{E}$ from 2003 to 2007 by (a) SCIAMACHY and (b) collocated IsoGSM. Regions in which the measurements did not pass the retrieval criteria are left blank. The shaded grid with dots represents the mean value of the average, which consists of at least 10 measurements within every $6 \mathrm{~h}$. The two lower panels show the same information as in (a-b) but for precipitable water $\left(\mathrm{kg} \mathrm{m}^{-2}\right)$ by (c) JRA25 and (d) IsoGSM.

IsoGSM, and the statistics are summarized in Table 2. Note that only the days for which observations were available were used to calculate the statistics. These measurements also showed the two isotopic minima of the year (W-shape): the first in August and September and the second in January, associated with the convective activity and large-scale subsidence, respectively. The model captures the two minima nicely and simulates the average and variability well, especially in the dry season. On the other hand, the model reveals rather poor reproducibility of day-to-day variation during the monsoon season; the depletion and variability were both overestimated. In the sensitivity experiment E10, the average and standard deviation (-14.9 and $1.8 \%$, respectively, for the monsoon season) were comparable with the observation $(-15.2$ and $1.8 \%$ ), and the correlation was slightly improved. Although this does not fully explain the discrep- 
Table 2. Averages (Ave.), standard deviations, their differences (simulations minus observations), and correlation coefficients (Cor.) for the simulations and observations from the 2010 to 2011 time series.

\begin{tabular}{|c|c|c|c|c|c|c|c|c|}
\hline & & \multicolumn{3}{|c|}{ Ave. [\%o] } & \multicolumn{3}{|c|}{$\mathrm{SD}[\% o]$} & \multirow[t]{2}{*}{ Cor. } \\
\hline & & Sim. & Obs. & Diff. & Sim. & Obs. & Diff. & \\
\hline \multirow[t]{3}{*}{ Std. } & whole period & -14.6 & -13.7 & 0.9 & 2.2 & 2.1 & 0.1 & $0.46^{*}$ \\
\hline & Monsoon season & -16.1 & -15.2 & 0.9 & 2.3 & 1.8 & 0.5 & 0.16 \\
\hline & Dry season & -14.7 & -15.0 & -0.3 & 1.7 & 1.6 & 0.1 & $0.63^{*}$ \\
\hline \multirow[t]{3}{*}{ E10 } & Whole period & -13.9 & & -0.2 & 1.7 & & -0.4 & $0.46^{*}$ \\
\hline & Monsoon season & -14.9 & & -0.3 & 1.8 & & 0.0 & 0.20 \\
\hline & Dry season & -15.2 & & -0.2 & 1.7 & & 0.1 & $0.64^{*}$ \\
\hline
\end{tabular}

${ }^{*} P<0.05$

ancy, it implies that the parameter controlling the equilibrium fraction $\varepsilon$ can be problematic. The positive points are that the $\delta^{18} \mathrm{O}_{\mathrm{v}}$ and precipitation averaged over previous days showed a strong correlation $(R<0.6)$ southwest of Niamey, as in the observation (Fig. S3 in Tremoy et al., 2012), which means that the relationship between convective activity and the $\delta^{18} \mathrm{O}_{\mathrm{v}}$ is well represented and that the time evolution on the monthly scale is comparable (thick lines in Fig. 3). The seasonal differences were similar, suggesting that SCIAMACHY may overestimate the seasonal variability.

\subsection{Evaluation of IsoGSM on the interannual scale}

Finally we evaluate the reproducibility of IsoGSM on the interannual scale. Although our target is the isotope ratio of near-surface water vapor, we use the isotope ratio of precipitation to validate the model reproducibility of surface vapor isotopes on the interannual timescale. There are two reasons for this: on the one hand, there is the lack of observations of vapor isotopes covering several years; the other is the fact that the isotopic composition of the precipitation is strongly constrained by that of the local lower-tropospheric vapor (Risi et al., 2008a). Hence the precipitation isotope represents surface vapor isotopes to some extent, and can be used to evaluate the reproducibility of vapor isotopes, even though they are not identical.

Figure 4 compares the modeled and observed time series of annual mean $\delta^{18} \mathrm{O}_{\mathrm{p}}$ at Niamey. Note that there are missing observations from 2000 to 2008 and after 2010 . The correlation between them is $0.74(P<0.05)$. The simulated (observed) annual average is $-4.6(-4.1 \%$ ) and the standard deviation is $1.2(1.1 \%$ ). The factors controlling the variability will be discussed in Sect. 4.

\subsection{Overview of IsoGSM evaluation}

To summarize the evaluation results, the spatial pattern in the mean state and the seasonal pattern driven by the Hadley circulation, monsoon flow, and convective activity are qualitatively well simulated with an emphasis on the reproducibility

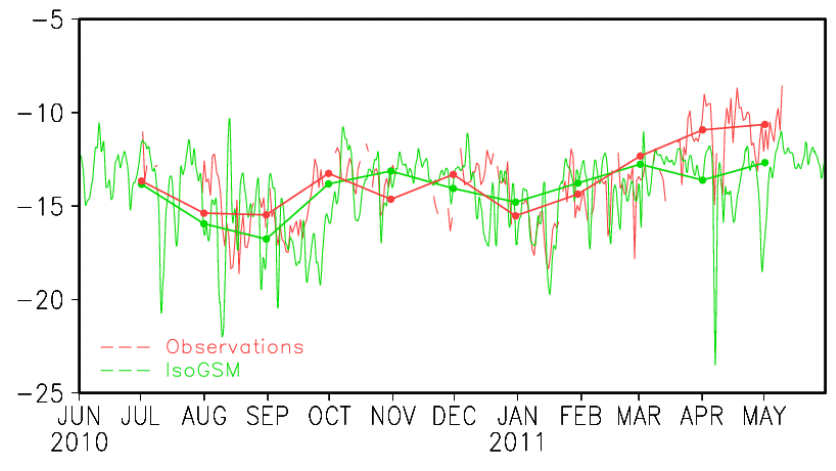

Figure 3. Temporal evolution from June 2010 to May 2011 of nearsurface $\delta^{18} \mathrm{O}_{\mathrm{v}}(\% \circ)$ : the thin red and green lines are the daily averaged observations and model values, respectively. The thick red and green lines connected by dots are the monthly averaged observations and model values, respectively.

of the interannual variability. When compared with SCIAMACHY measurements of $\delta \mathrm{D}$, there is a slight bias in the mean state, and IsoGSM largely underestimates the seasonal $\delta \mathrm{D}$ variations. When compared with the in situ measurements, the bias and variation differences are not as large as when compared with SCIAMACHY. Although the results of the simulation of the monsoon season are not as good as those of the dry season on the daily scale, IsoGSM captures the monthly-scale variability fairly well. These results suggest that the model is appropriate for studying the interannual variability of $\delta^{18} \mathrm{O}$ during the monsoon season.

\section{Simulated interannual variability of vapor isotopes}

\subsection{General features of interannual variability}

In this section, we explore the interannual variability of $\delta^{18} \mathrm{O}_{\mathrm{v}}$ over Niamey as given by the standard experiment. The simulation period is from 1979 to 2012 . The most striking feature of the interannual variability is that the depletion in the monsoon season does not appear every year in the model (Fig. 4 and Fig. 5). In contrast, $\delta^{18} \mathrm{O}_{\mathrm{v}}$ depletion oc- 


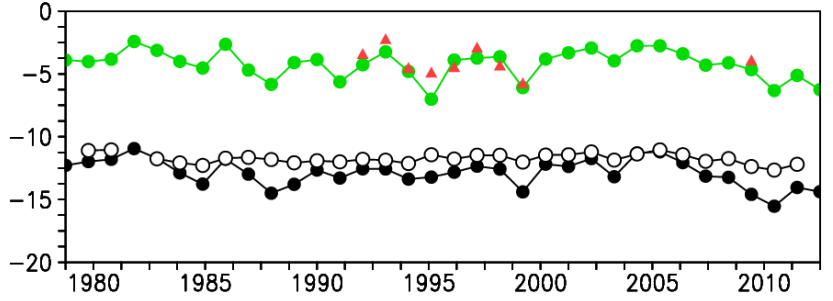

Figure 4. Interannual variability of annual mean $\delta^{18} \mathrm{O}_{\mathrm{p}}(\%$ ) at Niamey by the standard experiment (green) and by GNIP observation (red), together with that of near-surface $\delta^{18} \mathrm{O}_{\mathrm{v}}(\% \circ)$ during JAS at Niamey by the standard experiment (black) and the sensitivity experiment NoFrac (white).

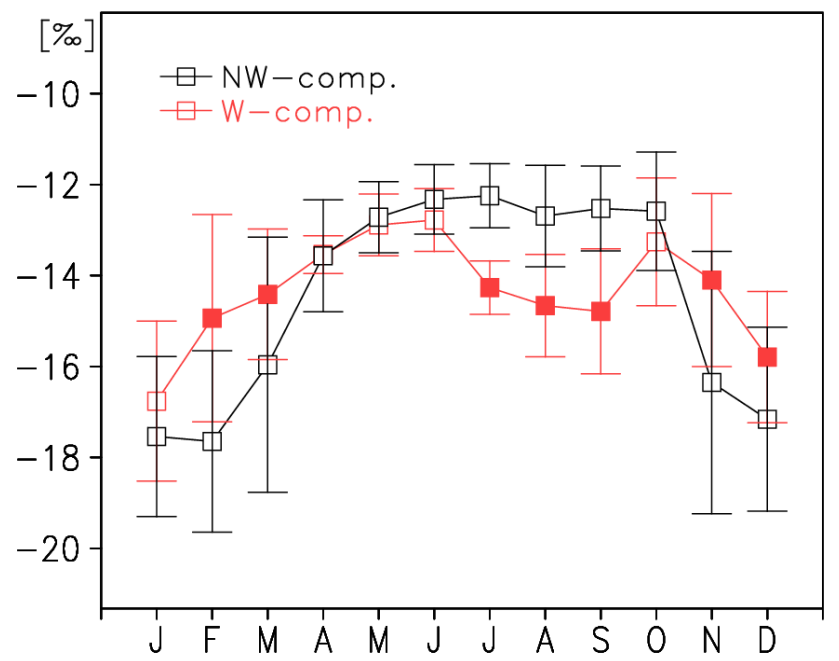

Figure 5. Seasonal variation of surface $\delta^{18} \mathrm{O}_{\mathrm{v}}(\% \circ)$ in W-shape years (red) and NW-shape years (black). Bars denote the interannual standard deviations for each month of the two composite fields. Closed red squares indicate that the monthly $\delta^{18} \mathrm{O}_{\mathrm{v}}$ in the W-shape year differs significantly from NW-shape year $(P<0.05)$.

curs each winter. We term the years with isotopic depletion in the monsoon season the "W-shape year" following Tremoy et al. (2012). To understand the factors controlling the interannual variability of $\delta^{18} \mathrm{O}_{\mathrm{v}}$, it is necessary to investigate the differences between the years with and without depletion. For the purpose of comparison, we set the criteria and made two composite fields: W-shape year composite and non-Wshape (NW-shape) year composite. The quantitative definition of a W-shape year is a year in which the surface vapor isotope value averaged over JAS in Niamey is $1 \sigma(1.1 \%$ ) less than that of the climatological average $(-12.9 \%$ ). We picked out six W-shape years (1988, 1999, 2009, 2010, 2011, and 2012) in the period; the rest are appointed to the NWshape composite. The seasonal variations in surface $\delta^{18} \mathrm{O}_{\mathrm{v}}$ in the two composite fields are shown in Fig. 5.

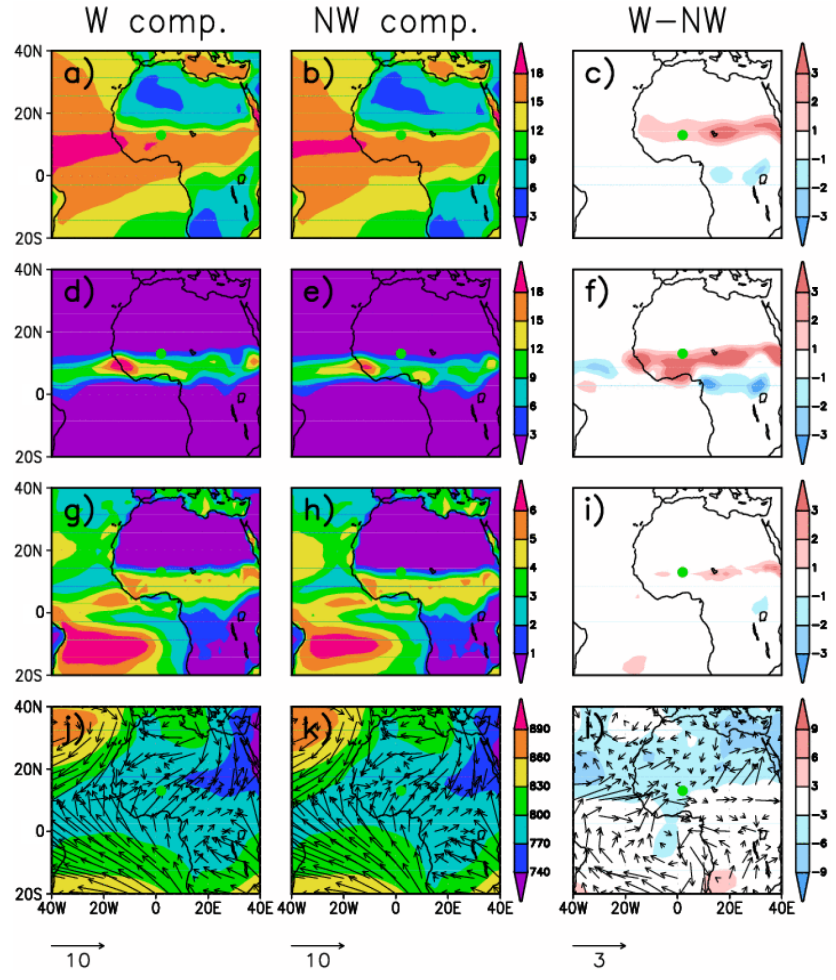

Figure 6. JAS average of $2 \mathrm{~m}$ height specific humidity $\left(\mathrm{g} \mathrm{kg}^{-1}\right)$ (a) in W-shape years, (b) in NW-shape years, and (c) the difference between them. Panels (d-f): same as (a-c) but for precipitation $\left(\mathrm{mm} \mathrm{day}^{-1}\right)$. Panels $(\mathbf{g}-\mathbf{i})$ : same as $(\mathbf{a}-\mathbf{c})$ but for evapotranspiration $\left(\mathrm{mm}\right.$ day $\left.^{-1}\right)$. Panels $(\mathbf{j}-\mathbf{l})$ : same as $(\mathbf{a}-\mathbf{c})$ but for geopotential height at $925 \mathrm{hPa}(\mathrm{gpm})$. Vectors denote wind at $925 \mathrm{hPa}$.

Here, we briefly discuss the features of the W-shape years. Figures 6 and 7 show the two composite fields and their differences (W-shape years minus NW-shape years) in the monsoon season. W-shape years are characterized by enhanced monsoon activity; the velocities of southwesterly winds over western Africa are higher (Fig. 6, panel l), and latitudes south of $10^{\circ} \mathrm{N}$ receive a larger amount of precipitation, especially on the Guinean coast and in the western and eastern Sahel (Fig. 6f). Due to the larger amount of precipitation, the level of evapotranspiration is also higher (Fig. 6i), and hence wetter conditions prevail (Fig. 6c) in W-shape years. The $\delta^{18} \mathrm{O}_{\mathrm{v}}$ is more depleted, as expected, centering on Niamey (Fig. 7c). The isotopic compositions of precipitation and evapotranspiration are also more depleted south of Niamey (Fig. 7f, i).

\subsection{Factors controlling $\delta^{18} \mathrm{O}_{\mathrm{v}}$ on interannual timescales}

To identify the mechanism responsible for the difference in isotopic variability between $\mathrm{W}$-shape and NW-shape years, isoflux analysis was applied to both composite fields. Here we analyze precipitable water instead of surface vapor for two reasons. The first is simplicity: by analyzing precipitable water, we do not have to consider at what height conden- 

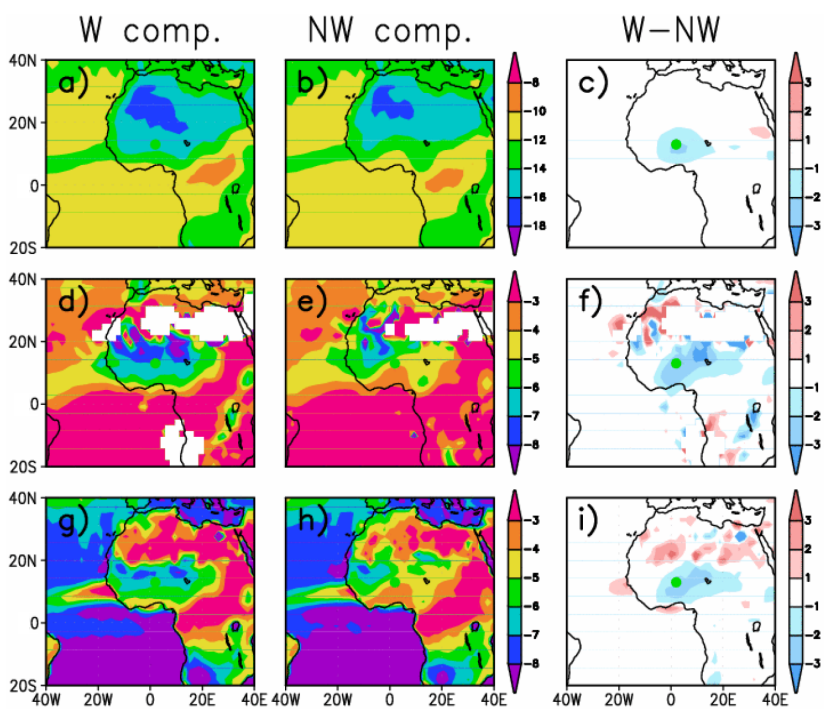

Figure 7. JAS average of isotopic composition of $2 \mathrm{~m}$ height vapor (\%o) (a) in W-shape years, (b) in NW-shape years, and (c) the difference between them. Panels $(\mathbf{d}-\mathbf{f})$ : same as $(\mathbf{a}-\mathbf{c})$ but for isotopic composition of precipitation $(\% o)$. Panels $(\mathbf{g}-\mathbf{i})$ : same as $(\mathbf{a}-\mathbf{c})$ but for isotopic composition in evapotranspiration (\%o).

sation and reevaporation take place, or the effect of vertical advection. The second reason is that most of the atmospheric water resides near the surface, and therefore the isotopic composition of precipitable water should be useful as a proxy for surface $\delta^{18} \mathrm{O}_{\mathrm{v}}$. This kind of alternation is also seen in Tremoy et al. (2012). As the analysis specifies the contribution of each factor to the change in the isotopic composition of precipitable water, the analysis period should start before the initiation of isotopic depletion and end at the most depleted point. Since the seasonal variation in the isotopic composition of precipitable water is almost the same as the surface $\delta^{18} \mathrm{O}_{\mathrm{v}}$ (Fig. 5), the analysis period was June-August to capture the decrease in the isotopic composition of precipitable water.

Figure 8 shows the results for the two composite fields in the Niamey grid cell. First, we discuss how each factor contributes to the $\delta_{\mathrm{W}}$ variation in general. Precipitation lowers $\delta_{\mathrm{W}}$, which is reasonable when considering the Rayleigh distillation model. This means that $\delta_{\mathrm{P}}$ is greater than $\delta_{\mathrm{W}}$; therefore, the effect of precipitation is always negative and contributes to lowering $\delta_{\mathrm{W}}$. Evapotranspiration works in the opposite way. As the model does not take fractionation into account on the land surface, $\delta_{\mathrm{E}}$ can be assumed to be a mixture of all precipitation (Yoshimura et al., 2008). Hence, $\delta_{\mathrm{E}}$ is presumably larger than $\delta_{\mathrm{W}}$, by the same analogy used to explain the effect of precipitation, and contributes to the increase in $\delta_{\mathrm{W}}$. The impact of advection in this form in Eq. (4) seems weaker compared with the other terms. However, the impact is the temporally averaged value. Given that advection sometimes lowers the $\delta_{\mathrm{W}}$ and sometimes enriches $\delta_{\mathrm{W}}$, the fact that the averaged value is very low does not readily imply that the impact itself is small. Therefore, we further decompose the effect of advection in Eq. (4) into

$\nabla \delta_{\mathrm{W}} \cdot \boldsymbol{Q}=\frac{\partial \delta_{\mathrm{W}}}{\partial y} \boldsymbol{Q}_{\mathrm{N}}+\frac{\partial \delta_{\mathrm{W}}}{\partial y} \boldsymbol{Q}_{\mathrm{S}}+\frac{\partial \delta_{\mathrm{W}}}{\partial x} \boldsymbol{Q}_{\mathrm{E}}+\frac{\partial \delta_{\mathrm{W}}}{\partial x} \boldsymbol{Q}_{\mathrm{W}}$,

where $\boldsymbol{Q}_{\mathrm{N}}, \boldsymbol{Q}_{\mathrm{S}}, \boldsymbol{Q}_{\mathrm{E}}$, and $\boldsymbol{Q}_{\mathrm{W}}$ represent the vertically integrated two-dimensional vapor flux vector from the north, south, east, and west, respectively. In this form, the impact of advection becomes clearer (Fig. 8b): southerly flow decreases $\delta_{\mathrm{W}}$, and easterly flow increases $\delta_{\mathrm{W}}$. The precipitation area in the south of Niamey which produces isotopically light moisture is considered to contribute decreased $\delta_{\mathrm{W}}$. On the other hand there is relatively less area with precipitation in the east of Niamey, which should produce isotopically heavier moisture compared with the southern part, contributing to increase $\delta_{\mathrm{W}}$ (Fig. 6). The impacts of the westerly flow and northerly flow are ambiguous and negligible.

The $\left(\mathrm{d} \delta_{\mathrm{W}} / \mathrm{d} t\right) \mathrm{W}$ is low in W-shape years $(P<0.05)$. Precipitation further lowers $\delta_{\mathrm{W}}$ and evapotranspiration further increases $\delta_{\mathrm{W}}$ in W-shape years, reflecting the larger amounts of precipitation and evapotranspiration. Although the differences between the impacts of the two composite fields are large, they are not significant because of the high degree of variation. The only term significantly different at $5 \%$ significance level other than $\left(\mathrm{d} \delta_{\mathrm{W}} / \mathrm{d} t\right) W$ is the impact of the southerly flow. When regressed with JAS-averaged surface $\delta^{18} \mathrm{O}_{\mathrm{v}}$ on the interannual timescale, the term that shows a strong correlation $(P<0.05)$ is the southerly flow alone. This suggests that the monsoon flow brings depleted moisture produced by heavier precipitation to the Niamey area, controlling the interannual variability of $\delta^{18} \mathrm{O}_{\mathrm{v}}$. The interannual regression field of JAS-averaged precipitation against Niamey surface $\delta^{18} \mathrm{O}_{\mathrm{v}}$ shows high correlation at the Guinea coast $\left(10^{\circ} \mathrm{W}-10^{\circ} \mathrm{E}, 0^{\circ}-10^{\circ} \mathrm{N}\right.$; Fig. 9). This indicates the relative importance of the distillation process during transport as compared to local precipitation for the interannual variability of $\delta^{18} \mathrm{O}_{\mathrm{v}}$ in western Africa.

In this regard, the correlation between $\delta^{18} \mathrm{O}_{\mathrm{v}}$ and precipitation east of Niamey, which is also located in the upstream region of Niamey, is expected to be strong because heavier precipitation falls in the eastern Sahel in W-shape years and the African Easterly Jet (AEJ) flows toward the Niamey region at heights above $800 \mathrm{hPa}$. The correlation for this region east of Niamey, however, is relatively weak $(|R|<0.4)$. As the southerly flow is dominant in the lower atmosphere $(1000-800 \mathrm{hPa})$ in the monsoon season, the relatively weak connection between surface $\delta^{18} \mathrm{O}_{\mathrm{v}}$ and precipitation east of Niamey is reasonable.

\subsection{Sensitivity experiment}

To confirm the contributions of the amount of precipitation that falls on the Guinea coast to the interannual variability in $\delta^{18} \mathrm{O}_{\mathrm{v}}$ at Niamey, we carried out the sensitivity experiment, 

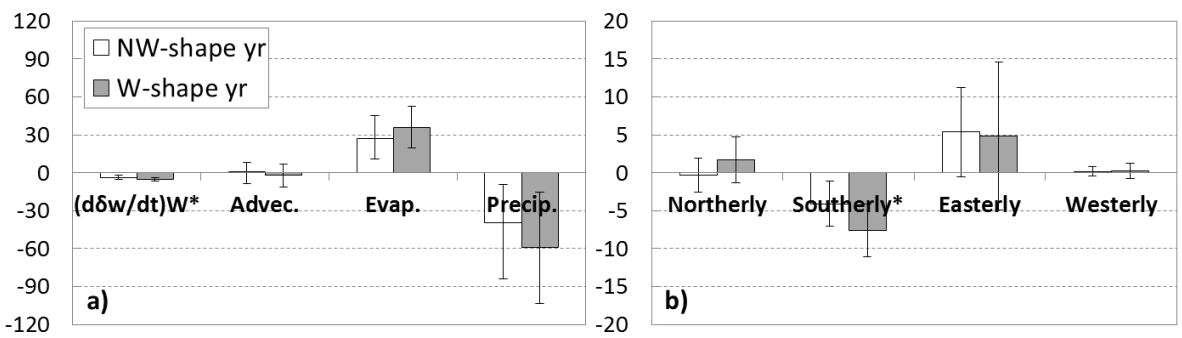

Figure 8. Panel (a): temporal derivative of isotopic composition in precipitable water during JJA and the contributions of advection, evapotranspiration, and precipitation to the vapor isotope change in NW-shape years (white) and W-shape years (grey) $\left(\% \circ \mathrm{mm} \mathrm{day}^{-1}\right)$. Panel (b): same as (a) but for the decomposed terms of the advection isoflux $\left(\% \circ \mathrm{mm}^{-1 a y}{ }^{-1}\right) .{ }^{*} P<0.05$ between two composites.

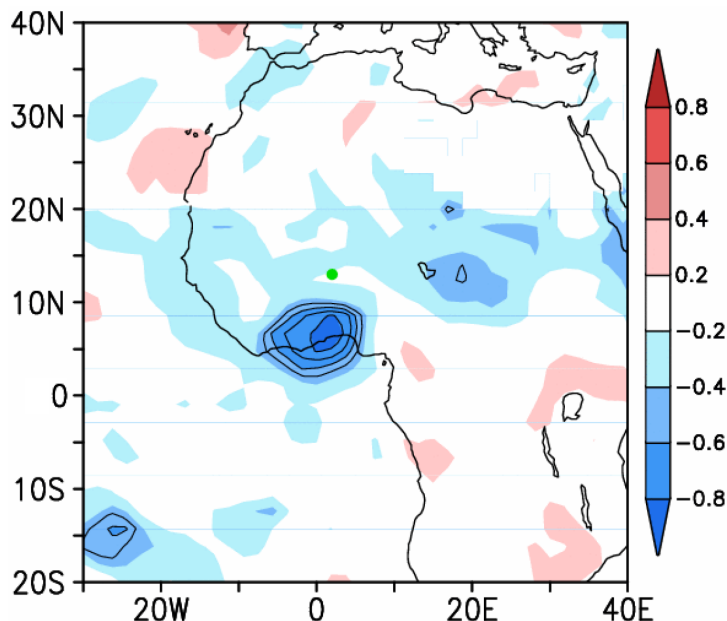

Figure 9. Correlation coefficient between JAS-averaged $\delta^{18} \mathrm{O}_{\mathrm{v}}$ at Niamey (green dot) and precipitation. The contoured area represents statistical significance $(P<0.01)$.

NoFrac, in which we removed the influence of the distillation process in the Guinea coast $\left(10^{\circ} \mathrm{W}-10^{\circ} \mathrm{E}, 0^{\circ}-10^{\circ} \mathrm{N}\right)$. As shown in Fig. 4, most of the interannual variability in $\delta^{18} \mathrm{O}_{\mathrm{v}}$ at Niamey was removed. In the standard experiment, the average $\delta^{18} \mathrm{O}_{\mathrm{v}}$ and the variance at Niamey are $-12.9 \%$ o and 1.16 , respectively, whereas they are $-11.7 \%$ and 0.15 , respectively, in NoFrac. The enriched average and considerably smaller variance in NoFrac confirm the key role of the Guinea coast precipitation in controlling the interannual variability of $\delta^{18} \mathrm{O}_{\mathrm{v}}$ at Niamey. In addition, we conducted other sensitivity experiments that were the same as the sensitivity experiment NoFrac but for the eastern Sahel $\left(10^{\circ}-30^{\circ} \mathrm{E}\right.$, $\left.10^{\circ}-20^{\circ} \mathrm{N}\right)$ and Niamey $\left(10^{\circ}-14^{\circ} \mathrm{E}, 11^{\circ}-15^{\circ} \mathrm{N}\right)$. Neither of these experiments showed a significant difference from the standard experiment (data not shown): the average and variance were $-12.8(-12.8 \%$ ) and $1.07(1.15)$, respectively, for the eastern Sahel (Niamey). These results exclude the impact of precipitation in the eastern Sahel or Niamey on controlling the interannual variability and enhance the robustness of our hypothesis.

\section{Relationship with ENSO}

Western African rainfall in the monsoon season has been connected to ENSO (e.g., Janicot et al., 2001; Joly et al., 2007; Losada et al., 2012); there is less precipitation during El Niño and more precipitation during La Niña. Given this connection, a relationship between $\delta^{18} \mathrm{O}_{\mathrm{v}}$ and ENSO through precipitation change is expected. Indeed, three of six W-shape years $(1988,1999$, and 2010) fell during a La Niña period. Therefore, we regressed JAS $\delta^{18} \mathrm{O}_{\mathrm{v}}$ from the model and annually averaged the NINO3 index calculated from the NCEP SST analysis, which was used to force the model. High positive correlations were found in all of western Africa (Fig. 10a). The spatial distribution of the correlation between the annual average of $\delta^{18} \mathrm{O}_{\mathrm{p}}$ weighted by monthly precipitation and the annual averaged NINO3 index was almost identical to that of the correlation between the $\delta^{18} \mathrm{O}_{\mathrm{v}}$ and the NINO3 index, but the correlated area over western Africa was confined to south of $15^{\circ} \mathrm{N}$ (Fig. 10b). To validate this, we also show the relationship between observed $\delta^{18} \mathrm{O}_{\mathrm{p}}$ from GNIP and the NINO3 index. The correlation pattern agreed well with GNIP over most of Africa; the highest positive correlation was in western Africa, a weak negative correlation was seen in the south of central and eastern Africa, and a weak positive correlation was found in southern Africa (Fig. 10c). All of the figures indicate that $\delta^{18} \mathrm{O}$ is significantly lower (higher) during the cold (warm) phase of ENSO over western Africa. The relationship between $\delta^{18} \mathrm{O}$ in western Africa and ENSO is evident from the figures. It results from the relationship between $\delta^{18} \mathrm{O}$ and western African precipitation, as discussed in Sect. 4 , and between the precipitation and ENSO. This mechanism is also found in the Asian and South American monsoon regions: ENSO governs precipitation, and the precipitation determines the interannual variability of the isotopic composition over the downstream regions (Vuille and Werner, 2005; Ishizaki et al., 2012).

ENSO is not the only mode affecting western African rainfall (Janicot et al., 2001); global warming, Interdecadal Pacific Oscillation (IPO), and Atlantic Multidecadal Oscillation (AMO) are found to have a significant impact (Mohino et al., 2011a) as well. Therefore, a nonstationary relation- 


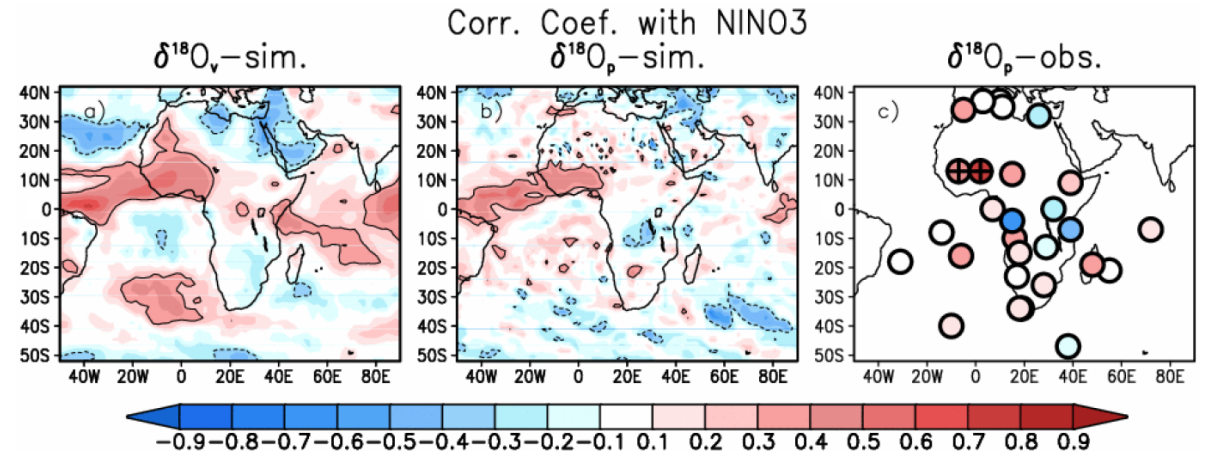

Figure 10. Correlation coefficient between annual averaged NINO3 index and (a) simulated July-September averaged vapor isotopes, (b) annual averaged simulated precipitation isotopes weighted by monthly precipitation, and (c) annual averaged observed precipitation isotopes weighted by monthly precipitation. Regions with significant positive (negative) correlations at the $90 \%$ confidence level are enclosed by solid (dotted) lines in (a) and (b). Sites with significant correlations at the $90 \%$ confidence level are indicated by crosses in (c).

ship between western African rainfall and ENSO (Janicot et al., 1996; Losada et al., 2012) has been reported, but this lies beyond the scope of the present study. Here, we wish to emphasize that we confirmed the statistical relationship between rainfall at the Guinea coast and ENSO in both the model $(R=-0.45, P<0.05)$ and observations (Global Precipitation Climatology Project, GPCP; Huffman et al., 2009) $(R=-0.43, P<0.05)$ during the period 1979-2012. Losada et al. (2012) also showed that this relationship became significant after the 1970s. Hence, we ensured the robustness of the relationship between the isotope ratio in surface vapor, precipitation, and ENSO over western Africa.

\section{Conclusion and outlook}

Here, we presented the interannual variability of $\delta^{18} \mathrm{O}_{\mathrm{v}}$ in western Africa and its relationship to ENSO using the nudged IsoGSM model (Yoshimura et al., 2008). Our simulation indicated that the isotopic depletion in the monsoon season, which was reported by Risi et al. (2010) and Tremoy et al. (2012), does not occur every year. The main driver of the depletion was found to be precipitation at the Guinea coast. Furthermore, we found a relationship between $\delta^{18} \mathrm{O}$ over western Africa and ENSO: ENSO modulates the interannual variability of $\delta^{18} \mathrm{O}$ via precipitation at the Guinea coast.

We showed the ability of the model to simulate intraseasonal to interannual timescale variability, but the model performed relatively poorly on the daily scale. The parameter controlling the equilibrium fraction $\varepsilon$ is suggested to be problematic. Another possibility is the lack of isotopic fractionation over the land surface. Risi et al. (2013) demonstrated the importance of continental recycling and sensitivity to model parameters that modulate evapotranspiration over western Africa. They indicated the importance of taking land surface fractionation into account. As IsoGSM assumes that isotopic fractionation does not occur over the land surface, coupling with more sophisticated land surface models would allow more accurate simulations. Similarly, an atmosphereocean-coupled model with stable isotopes is desirable to determine how ENSO impacts the isotope ratio above water more clearly.

One of the expected roles of isotope-enabled GCMs is to find "hot spots" - i.e., places in which a climate proxy is sensitive to climate change - for climate reconstruction. Here, we propose that $\delta^{18} \mathrm{O}$ at Niamey may be a good proxy of western African rainfall and its relationship to ENSO. Indeed, we found a good correlation between the simulated $\delta^{18} \mathrm{O}$ and a climate proxy from Ghana, which has an ENSO signal (Shanahan et al., 2009) for their overlapping period ( $R=0.65, P<0.01)$. Despite the strong correlation, however, ENSO is certainly not the only mode modulating $\delta^{18} \mathrm{O}$ in the area. In our simulation, the last 4 years were counted as W-shape years, in which surface $\delta^{18} \mathrm{O}_{\mathrm{v}}$ was lower at Niamey and precipitation over western Africa was higher, even though not all of these were La Niña years. This may reflect the recent La Niña-like trend associated with the hiatus (Kosaka and Xie, 2013; England et al., 2014), supporting the impact of Interdecadal Pacific Oscillation (IPO) on western African rainfall on a multidecadal timescale (Mohino et al., 2011a). On the other hand, Shanahan et al. (2009) reconstructed western African rainfall variability from the sediments of a lake in Ghana, supporting the suggestion that Atlantic SST controls multidecadal variability. Further comparisons with in situ observations and climate proxies would be of interest.

This study confirms the relationship between western African rainfall and isotopic variability on the interannual timescale, which enables us to reconstruct detailed western African rainfall, and this should help disentangle the nonstationarity of the impact of various SST basins on western Africa rainfall. 
Acknowledgements. The first author is supported by the Japan Society for the Promotion of Science (JSPS) via a Grant-in-Aid for JSPS Fellows. Part of this research was supported by the SOUSEI from MEXT, Japan, CREST from JST, Japan, JSPS KAKENHI Grant Numbers 23686071, 26289160, and the GCOE for Sustainable Urban Regeneration at the University of Tokyo. R. Scheepmaker acknowledges support from the Netherlands Space Office as part of the User Support Programme Space Research project $\mathrm{GO}-\mathrm{AO} / 16$.

Edited by: P. Jöckel

\section{References}

Aronson, R. B., Precht, W. F., Macintyre, J. G., and Murdoch, T. J. T.: Coral bleach-out in Belize, Nature, 405, p. 36, doi:10.1038/35011132, 2000.

Berkelhammer, M., Stott, L., Yoshimura, K., Johnson, K., and Sinha, A.: Synoptic and mesoscale controls on the isotopic composition of precipitation in the western US, Clim. Dynam., 38, 433-454, 2012.

Brown, J., Simmonds, I., and Noone, D.: Modeling $\delta^{18} \mathrm{O}$ in tropical precipitation and the surface ocean for present-day climate, J. Geophys. Res., 111, D05105, doi:10.1029/2004JD005611, 2006.

Cai, W., Borlace, S., Lengaigne, M., Rensch, P., Collins, M., Vecchi, G., Timmermann, A., Santoso, A., McPhaden, M. J., Wu, L., England, M. H., Wang, G., Guilyardi, E., and Jin, F.-F.: Increasing frequency of extreme El Niño events due to greenhouse warming, Nat. Clim. Change, 4, 111-116, doi:10.1038/NCLIMATE2100, 2014.

Dai, A., Fung, I. Y., and Del Genio, A. D.: Surface observed global land precipitation variations during 1900-88, J. Climate, 10, 2943-2962, 1997.

Dansgaard, W.: Stable isotopes in precipitation, Tellus, 16, 436468, 1964

England, M. H., McGregor, S., Spence, P., Meehl, G. A., Timmermann, A., Cai, W., Gupta, A., McPhaden, M. J., Purich, A., and Santoso, A.: Recent intensification of wind-driven circulation in the Pacific and the ongoing warming hiatus, Nat. Clim. Change, 4, 222-227, 2014.

Frankenberg, C., Yoshimura, K., Warneke, T., Aben, I., Butz, A., Deutscher, N., Griffith, D., Hase, F., Notholt, J., Schneider, M., Schrijver, H., and Röckmann, T.: Dynamic processes governing lower-tropospheric $\mathrm{HDO} / \mathrm{H}_{2} \mathrm{O}$ ratios as observed from space and ground, Science, 325, 1374-1377, 2009.

Folland, C. K., Palmer, T. N., and Parker, D. E.: Sahel rainfall and worldwide sea temperatures, 1901-85, Nature, 320, 602-607, 1986.

Giannini, A., Saravanan, R., and Chang, P.: Oceanic forcing of Sahel rainfall on interannual to interdecadal time scales, Science, 302, 1027, doi:10.1126/science.1089357, 2003.

Huffman, G. J., Alder, R. F., Bolvin, D. T., and Gu, G.: Improving the global precipitation record: GPCP Version 2.1, Geophys. Res. Lett., 36, L17808, doi:10.1029/2009GL040000, 2009.

IAEA/WMO, Global Network of Isotopes in Precipitation, The GNIP Database, available at: http://www.iaea.org/water, last access: 8 May 2014.
Ishizaki, Y., Yoshimura, K., Kanae, S., Kimoto, M., Kurita, N., and Oki, T.: Interannual variability of $\mathrm{H}_{2}^{18} \mathrm{O}$ in precipitation over the Asian monsoon region, J. Geophys. Res., 117, D16308, doi:10.1029/2011JD015890, 2012.

Janicot, S., Moron, V., and Fontaine, B.: Sahel droughts and ENSO dynamics, Geophys. Res. Lett., 23, 515-518, 1996.

Janicot, S., Trzaska, S., and Poccard, I.: Summer Sahel-ENSO teleconnection and decadal time scale SST variations, Clim. Dynam., 18, 303-320, 2001.

Janicot, S., Thorncroft, C. D., Ali, A., Asencio, N., Berry, G., Bock, O., Bourles, B., Caniaux, G., Chauvin, F., Deme, A., Kergoat, L., Lafore, J.-P., Lavaysse, C., Lebel, T., Marticorena, B., Mounier, F., Nedelec, P., Redelsperger, J.-L., Ravegnani, F., Reeves, C. E., Roca, R., de Rosnay, P., Schlager, H., Sultan, B., Tomasini, M., Ulanovsky, A., and ACMAD forecasters team: Large-scale overview of the summer monsoon over West Africa during the AMMA field experiment in 2006, Ann. Geophys., 26, 25692595, doi:10.5194/angeo-26-2569-2008, 2008.

Joly, M. and Voldoire, A.: Role of Gulf of Guinea in the interannual variability of the West African monsoon: what do we learn from CMIP3 coupled simulations?, Int. J. Climatol., 30, 1843-1856, 2010.

Joly, M., Voldoire, A., Douville, H., Terray, P., and Royer, J.-F.: African monsoon teleconnections with tropical SSTs: validation and evolution in a set of IPCC4 simulations, Clim. Dynam., 29, $1-20,2007$.

Joussaume, S., Sadourny, R., and Jouzel, J.: A general circulation model of water isotope cycles in the atmosphere, Nature, 311 , 24-29, 1984.

Kanamitsu, M., Ebisuzaki, W., Woolen, J., Potter, J., and Fiorino, M.: NCEP-DOE AMIP-II Reanalysis (R-2), B. Am. Meteorol. Soc., 83, 1631-1643, 2002.

Kosaka, Y. and Xie, S.-P.: Recent global-warming hiatus tied to equatorial Pacific surface cooling, Nat. Clim. Change, 501, 403407, 2013.

Lai, C.-T., Ehleringer, J. R., Bond, B. J., and Paw, U. K. T.: Contributions of evaporation, isotopic non-steady state transpiration and atmospheric mixing on the $\delta^{18} \mathrm{O}$ of water vapour in Pacific Northwest coniferous forests, Plant Cell Environ., 29, 77-94, 2006.

Lamb, P. J.: Large-scale tropical Atlantic surface circulation patterns associated with Subsaharan weather anomalies, Tellus, 30 , 240-251, 1978.

Lee, J.-E., Risi, C., Fung, I., Worden, J., Scheepmaker, R. A., Linder, B., and Frankenberg, C.: Asian monsoon hydrometeorology from TES and SCIAMACHY water vapor isotope measurements and LMDZ simulations: Implications for speleothem climate record interpretation, J. Geophys. Res., 117, D15112, doi:10.1029/2011JD017133, 2012

Lézine, A.-M. and Casanova, J.: Pollen and hydrological evidence for the interpretation of past climates in tropical West Africa during the Holocene, Quaternary Sci. Rev., 8, 45-55, 1989.

Liu, G., Kojima, K., Yoshimura, K., Okai, T., Suzuki, A., Oki, T., Siringan, F. P., Yoneda, M., and Kawahata, H.: A model-based test of accuracy of seawater oxygen isotope ratio record derived from a coral dual proxy method at southeastern Luzon Island, the Philippines, J. Geophys. Res.-Biogeo., 118, 853-859, 2013.

Liu, Z., Yoshimura, K., Bowen, G. J., Buenning, N. H., Risi, C., Welker, J. M., and Yuan, F.: Paired oxygen isotope 
records reveal modern North American atmospheric dynamics during the Holocene, Nature communications, 5, 3701, doi:10.1038/ncomms4701, 2014.

Losada, T., Rodiriguez-Fonseca, B., Mohino, E., Bader, J., Janicot, S., and Mechoso, C. R.: Tropical SST and Sahel rainfall: A non-stationary relationship, Geophys. Res. Lett., 39, L12705, doi:10.1029/2012GL052423, 2012.

Mohino, E., Janicot, S., and Bader, J.: Sahel rainfall and decadal to multi-decadal sea surface temperature variability, Clim. Dynam., 37, 419-440, 2011a.

Mohino, E., Rodriguez-Fonseca, B., Losada, T., Gervois, S., Janicot, S., Bader, J., Ruti, P., and Chauvin, F.: Changes in the interannual SST-forced signals on West African rainfall. AGCM intercomparison, Clim. Dynam., 37, 1707-1725, $2011 \mathrm{~b}$.

Moorthi, S. and Suarez, S. J.: Relaxed Arakawa-Schubert: A parameterization of moist convection for general circulation models, Mon. Weather Rev., 120, 978-1002, 1992.

Nicholson, S. E.: The West African Sahel: A review of recent studies on the rainfall regime and its interannual variability, ISRN Meteorology, 2013, 1-32, 2013.

Onogi, K., Tsusui, J., Koide, H., Sakamoto, M., Kobayashi, S., Hatsushika, H., Matsumoto, T., Yamazaki, N., Komahori, H., Takahashi, K., Kadokura, S., Wada, K., Kato, K., Oyama, R., Ose, T., Mannoji, N., and Taira, R.: The JRA-25 Reanalysis, J. Meteorol. Soc. JPN, 85, 369-432, 2007.

Palmer, T. N.: Influence of the Atlantic, Pacific and Indian Ocean on Sahel rainfall, Nature, 322, 251-253, 1986.

Philander, S. G. H.: Anomalous El Niño of 1982-1983, Nature, 305, p. 16, doi:10.1038/305016a0, 1983.

Polo, I., Rodriguez-Fonseca, B., Losada, T., and Garcia-Serrano, J.: Tropical Atlantic variability modes (1979-2002). Part I: Timeevolving SST modes related to West African rainfall, J. Climate, 21, 6457-6475, 2008.

Risi, C., Bony, S., and Vimeux, F.: Influence of convective processes on the isotopic composition $\left(\delta^{18} \mathrm{O}\right.$ and $\left.\delta \mathrm{D}\right)$ of precipitation and water vapor in the tropics: 2. Physical interpretation of the amount effect, J. Geophys. Res., 113, D19306, doi:10.1029/2008JD009943, 2008a.

Risi, C., Bony, S., Vimeux, F., Descroix, L., Ibrahim, B., Lebreton, E., Mamadou, I., and Sultan, B.: What controls the isotopic composition of the African monsoon precipitation? Insights from event-based precipitation collected during the 2006 AMMA field campaign, Geophys. Res. Lett., 35, L24808, doi:10.1029/2008GL035920, 2008b.

Risi, C., Bony, S., Vimeux, F., Frankenberg, C., Noone, D., and Worden, J.: Understanding the Sahelian water budget through the isotopic composition of water vapor and precipitation, J. Geophys. Res., 115, D24110, doi:10.1029/2010JD014690, 2010.

Risi, C., Noone, D., Frankenberg, C., and Worden, J.: Role of continental recycling in intraseasonal variations of continental moisture as deduced from model simulations and water vapor isotopic measurements, Water Resour. Res., 49, 4136-4156, 2013.
Rowell, D. P.: The impact of Mediterranean SSTs on the Sahelian rainfall season, J. Climate, 16, 849-862, 2003.

Scheepmaker, R. A., Frankenberg, C., Deutscher, N. M., Schneider, M., Barthlott, S., Blumenstock, T., Garcia, O. E., Hase, F., Jones, N., Mahieu, E., Notholt, J., Velazco, V., Landgraf, J., and Aben, I.: Validation of SCIAMACHY HDO/ $\mathrm{H}_{2} \mathrm{O}$ measurements using the TCCON and NDACC-MUSICA networks, Atmos. Meas. Tech. Discuss., 7, 11799-11851, doi:10.5194/amtd7-11799-2014, 2014.

Schmidt, G. A., LeGrande, A., and Hoffmann, G.: Water isotope expressions of intrinsic and forced variability in a coupled ocean-atmosphere model, J. Geophys. Res., 112, D10103, doi:10.1029/2006JD007781, 2007.

Shanahan, T. M., Overpeck, J. T., Anchukaitis, K. J., Beck, J. W., Cole, J. E., Dettman, D. L., Peck, J. A., Scholz, C. A., and King, J. W.: Atlantic forcing of persistent drought in West Africa, Science, 324, 377-380, 2009.

Tindall, J. C., Valdes, P. J., and Sime, L. C.: Stable water isotopes in HadCM3: Isotopic signature of El Niño-Southern Oscillation and tropical amount effect, J. Geophys. Res., 114, D04111, doi:10.1029/2008JD010825, 2009.

Tremoy, G., Vimeux, F., Mayaki, S., Souley, I., Cattani, O., Risi, C., Favreau, G., and Oï, M.: A 1-year long $\delta^{18} \mathrm{O}$ record of water vapor in Niamey (Niger) reveals insightful atmospheric processes at different timescales, Geophys. Res. Lett., 39, L08805, doi:10.1029/2012GL051298, 2012.

Tremoy, G., Vimeux, F., Soumana, S., Souley, I., Risi, C., Favreau, G., and Oï, M.: Clustering mesoscale convective systems with laser-based water vapor $\delta^{18} \mathrm{O}$ monitoring in Niamey (Niger), J. Geophys. Res., 119, 5079-5013, doi:10.1002/2013JD020968, 2014.

Vuille, M. and Werner, M.: Stable isotopes in precipitation recording South American summer monsoon and ENSO variability: observations and model results, Clim. Dynam., 25, 401-413, 2005.

Ward, N.: Diagnosis and short-lead time prediction of summer rainfall in tropical North Africa at interannual and multidecadal timescales, J. Climate, 11, 3167-3191, 1998.

Werner, M., Langebroek, P. M., Carlsen, T., Herold, M., and Lohmann, G.: Stable water isotopes in the ECHAM5 general circulation model: Toward high-resolution isotope modeling on a global scale, J. Geophys. Res., 116, D15109, doi:10.1029/2011JD015681, 2011.

Worden J., Noone, D., and Bowmann, K.: Importance of rain evaporation and continental convection in the tropical water cycle, Nature, 445, 528-532, 2007.

Yoshimura, K., Kanamitsu, M., Noone, D., and Oki, T.: Historical isotope simulation using Reanalysis atmospheric data, J. Geophys. Res., 113, D19108, doi:10.1029/2008JD010074, 2008.

Yoshimura, K., Frankenberg, C., Lee, J., Kanamitsu, M., Worden, J., and Röckmann, T.: Comparison of an isotopic atmospheric general circulation model with new quasi-global satellite measurements of water vapor isotopologues, J. Geophys. Res., 116, D19118, doi:10.1029/2011JD016035, 2011. 